\title{
CAMBIOS AMBIENTALES Y SISTEMAS DE ASENTAMIENTO EN EL ÁRIDO NORMENDOCINO.
}

\author{
ARQUEOLOGÍA EN LOS \\ PALEOCAUCES DEL RÍO MENDOZA.
}

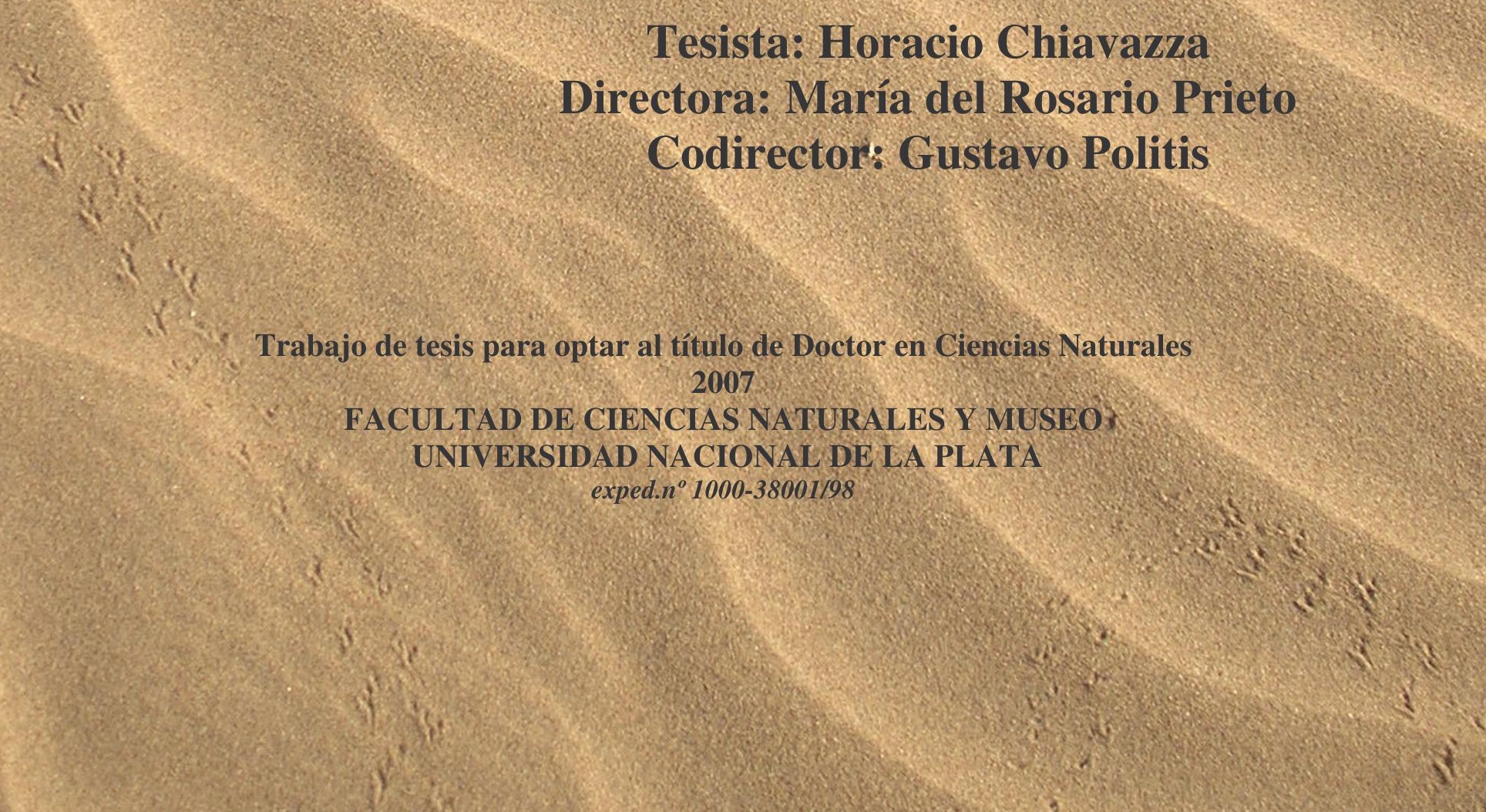

